\title{
THE BIG FOUR: A STUDY OF THE COMPATIBILITY OF ACCOUNTING AND CONSULTING PRACTICES WITHIN A PROFESSIONAL SERVICES FIRM IN THE UNITED STATES
}

\author{
Benoit N Boyer, Sacred Heart University, U.S.A. \\ Danny Pannese, Sacred Heart University, U.S.A.
}

dx.doi.org/10.18374/JABE-20-3.14

\begin{abstract}
The Big Four audits approximately $99 \%$ of the market capitalization of companies traded on the New York Stock Exchange (NYSE) and the National Association of Securities Dealers Automated Quotations (NASDAQ) that are included in the Fortune 500. The purpose of our study is to provide data driven analysis about 1) the relationship between audit quality and permissible non-audit consulting/advisory providers to audit clients by the auditor and 2) the impact on audit quality of providing consulting/advisory services to non-audit clients of the Big Four. Evidence will be presented to demonstrate that as consulting/ advisory service revenue has increased, audit quality has also increased. Audit independence has been safeguarded.
\end{abstract}

Keywords: Big Four, Independence, Audit Quality, Consulting Services 